\title{
Lewis and Bronsted acid-containing ionic liquids with dual activation mode for the styrene polymerization
}

\author{
Thyago S. Rodrigues ${ }^{\star a}$ (IC), Gisele A. Medeiros ${ }^{a}$ (IC), Raquel R. Marques ${ }^{a}$ (IC), \\ Fabrício M. Silva ${ }^{a}(P Q)$, Brenno A. D. Neto ${ }^{a}(P Q)$ \\ ${ }^{a}$ Laboratory of Medicinal and Technolical Chemistry - University of Brasilia, Chemistry Institute (IQ-UnB). \\ *thyagosrodrigues@hotmail.com
}

Keywords: Ionic liquids, styrene, polymerization.

\section{INTRODUCTION}

Ionic liquids (ILs) are organic salts at room or close to room temperature and pressure conditions. Most often, they are colorless and present relatively low viscosity, negligible vapor pressure, low flammability and high ionic conductivity. Indeed, they are a great media for a plethora of reactions and are capable to dissolve a large number of organic and inorganic compounds.

Their unique physical-chemical properties render those liquids a very attractive condition to be used in cationic polymerization of vinyl monomers. ${ }^{2}$

In this work, we describe the synthesis and application of a Lewis and Bronsted acid-containing ionic liquids with dual activation mode for the styrene polymerization.

\section{RESULTS AND DISCUSSION}

ILs are commonly used as efficient media to conduct polymerization reactions. However, the use of additive initiators are frequently required to succeed the desired reaction. For instance, benzoyl peroxide, aryl and akyl chlorides can be added in the reaction media as initiators.

In Scheme 1 and 2 it is shown the synthesis of an ionically-tagged Bronsted acid derivative and the formation of a novel catalyst with dual mode activation. These catalysts combine both the properties of a Lewis and Bronsted acids.<smiles>Cn1ccnc1</smiles><smiles>O=C(O)CCl</smiles>

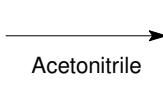

$48 \mathrm{~h}$

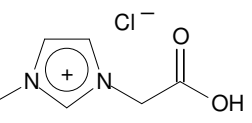

Scheme 1. Synthesis of the ionically-tagged Bronsted acid derivative.

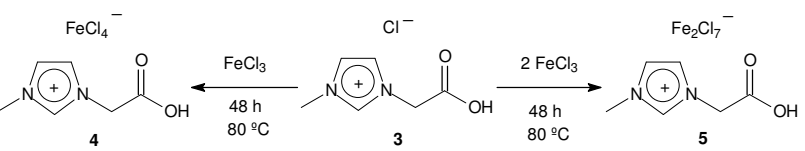

Scheme 2. Syntheses of novel dual activation mode catalysts.

Reaction between $\mathrm{FeCl}_{3}$ and 3 results in the formation of two new catalysts of general formulation $\mathrm{C}_{6} \mathrm{H}_{9} \mathrm{~N}_{2} \mathrm{O}_{2} \cdot \mathrm{Fe}_{\mathrm{x}} \mathrm{Cl}_{3 \mathrm{x}+1}(\mathrm{X}=1$ or 2$)$.
Both catalysts have their activity tested as the promoters of styrene polymerization (Table 1).

Table 1. Activity catalyst MAI.Fe $\mathrm{Cl}_{3 x+1}(\mathrm{X}=1$ or 2$)$ supported in different IL.

\begin{tabular}{|c|c|c|c|c|}
\hline Entry ${ }^{\mathrm{a}}$ & Catalyst & $\begin{array}{c}\mathrm{IL} \\
(0.5 \mathrm{~mL})\end{array}$ & $\begin{array}{l}\text { Time } \\
\text { (days) }\end{array}$ & $\begin{array}{c}\text { Yield } \\
(\%)\end{array}$ \\
\hline 1 & $\mathrm{MAI} \mathrm{FeCl}_{4}$ & - & $40^{b}$ & 85 \\
\hline 2 & MAI. $\mathrm{Fe}_{2} \mathrm{Cl}_{7}$ & - & $11^{\mathrm{b}}$ & 93 \\
\hline 3 & $\mathrm{MAI} \mathrm{FeCl}_{4}$ & BMI.NTf 2 & 5 & - \\
\hline 4 & MAI. $\mathrm{Fe}_{2} \mathrm{Cl}_{7}$ & BMI.NTf $_{2}$ & $12^{b}$ & 99 \\
\hline 5 & $\mathrm{MAI} \mathrm{FeCl}_{4}$ & BMI.PF 6 & 5 & 85 \\
\hline 6 & MAI. $\mathrm{Fe}_{2} \mathrm{Cl}_{7}$ & BMI.PF 6 & 5 & 4 \\
\hline 7 & MAI.FeCl 4 & BMI.BF 4 & 5 & - \\
\hline 8 & MAI. $\mathrm{Fe}_{2} \mathrm{Cl}_{7}$ & $\mathrm{BMI} \mathrm{BF}_{4}$ & 5 & 2 \\
\hline
\end{tabular}

It is noted that the efficiency of catalyst $\mathbf{5}$ is far better than catalyst 4 .

The best result was achieved using catalyst $\mathbf{5}$ immobilised in BMI.NTf 2 (Table 1, Entry 4). It is also noted the enhanced ionic liquid effect through reaction time and yields.

\section{CONCLUSION}

Catalyst 5 showed highly efficiency as the promoter of styrene polymerization reactions. The use of ILs as the reaction media showed a beneficial effect in the reaction time and yield. Further studies are under way to a better understand of the transformation.

\section{ACKNOWLEDGEMENTS}

FAPDF, CAPES, FINATEC e CNPq for the financial support.

\section{REFERENCES}

${ }^{1}$ Bueno, C.; Cabral, V. F.; Cardozo-Filho, L.; Dias, M.L. and Antunes

O.A.C. J. of Supercritical Fluids 2009, 48, 183-187.

${ }^{2}$ Kubisa, P. J. Polym. Sci. part A: polym. chem. 2005, 43, 4675 - 4683. 